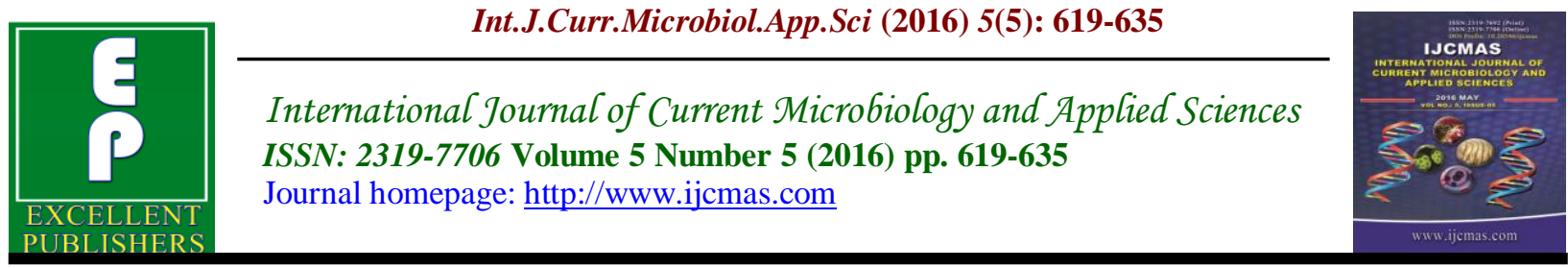

Original Research Article

http://dx.doi.org/10.20546/ijcmas.2016.505.063

\title{
Enhancement of Protease Production of Some Bacillus spp. Isolated from Various Regions in Jeddah City
}

\author{
Effat A.M. Soliman ${ }^{1,2^{*}}$, O.I.M. El-Hamshary ${ }^{1,2}$ and Reem S.M. Batayyib ${ }^{2}$ \\ ${ }^{1}$ Microbial Genetic Dept., National Research Centre, 33 El-Bohouth St \\ (Former El-Tahrir St.) Dokki, Giza, Egypt, P.O. 12662 \\ ${ }^{2}$ Biological Science Dept., Fac. of Science, King Abdulaziz University, Jeddah, KSA \\ *Corresponding author
}

\begin{abstract}
A B S T R A C T
Keywords

Bacillus spp.,

UV irradiation,

Ethidium

Bromide,

Plasmid

curing,

Protease.

\section{Article Info}

Accepted:

18 April 2016

Available Online:

10 May 2016

In this study, we aimed to increase the protease production of some Bacillus isolates obtained from Jeddah City. Among fifty-four isolates, four isolates were the highest productive, J1, KA6, F5 and M4. They gave 10.76, 10.50, 10.30 and 9.36 U/ml, respectively. They were assigned as Bacillus BS, BP, BT and BL. The highest productive strains were subjected to mutagenesis using UV irradiation and Ethidium bromide. Out of fifty-two mutants, four mutants exhibited high efficiency of protease production. They were BL4-1, RS6-1, BETL0-1 and BETP40-2.They gave $25.98,22.10,19.74$ and $14.92 \mathrm{U} / \mathrm{ml}$, respectively. BL4-1 gave productivity threefold than Bacillus BL parental strain while RS6-1 gave two fold than Bacillus BS. Generally, UV irradiation was more efficient than EtBr in obtaining mutants with higher efficiency. Top highest mutants, BL4-1, RS6-1, and their parental strains were subjected to plasmid curing. Curing of Bacillus BL by elevated temperature has no effect on production while curing with acridine orange; production was increased. BL4-1 mutant showed great decrease in productivity by acridine orange compared to elevated temperature. In case of Bacillus BS parental strain, productivity was increased after curing with acridine orange while with elevated temperature the increase was medium. Production was not significantly affected by acridine orange in RS6-1 mutant while decrease sharply by elevated temperature.
\end{abstract}

\section{Introduction}

To obtain high yielding productive strains, chemical and physical mutagens are promising agents to achieve this goal (Sidney and Nathan, 1975). The productivity of microorganisms, that is known to be important in producing economic enzymes, is controlled by the organism's genomeal though their yield may been enhancing and increased by optimizing their cultural conditions (Stanbury et al., 1995). Ultraviolet irradiation (UV) is the best mutagenic agent in prokaryotic organisms. It also characterized as the most proper mutagens to be employed in obtaining high yielding productive strains. UV irradiation covers all kinds of base pair substitutions and gives a high ratio of pyrimidine 
dimmers (Roja and Prasad, 2012). On the other hand, chemical mutagens are powerful mutagenic agents that responsible in the occurring of changes in DNA sequence (Miller, 1972). They also affect the replication of DNA (Haq et al., 2002, Besoain et al., 2007). Ethidium bromide was used as a mutagen because itreacts with DNA bases and insert among them (Waring, 1965). Due to this insertion, DNA become more stretch and as a result, frame shift mutations occurred. This result affects the replication and transcription of DNA as reported by (Suribabu et al., 2014). Great number of articles reported and explained the efficient use of physical and chemical mutagens. They proved the importance and effectiveness of these mutagens to be applied to improve the productivity of bacterial strains that produce various important industrial enzymes like protease and lipase (Soliman et al., 2004, Nadeem et al., 2006, Jamal et al., 2011).Alkaline proteases are one of the most widely studied groups of enzymes that have commercial value because of their use in multiple applications in various industrial sectors (Jasvir et al., 2004; Javed et al., 2013). Their sales exceeding more than $60 \%$ of the total worldwide enzymes sales. They widely used in many various industries like leather processing, meat processing, dairy, detergent additives and for many other uses (Chellappan et al., 2006, Prakasham et al., 2006). Today, proteases are mainly used in detergent industry and originated from the genus of Bacillus (Roger et al., 2002).Bacteria belong to genus of Bacillus are participated in the enzyme industry and known to produce proteolytic enzymes efficiently and effectively (Boominadhan et al., 2009). Microbes producing proteases enzymes serve as the preferred source of proteases due to several factors. These factors include their rapid growth, limited spaces that needed for their cultivation, and can be genetically manipulated easily to produce new enzymes with altered properties. The present study mainly focused to strain improvement of some Bacillus strains isolated from various regions in Jeddah City through mutation for enhanced production of protease enzyme.

\section{Materials and Methods}

\section{Media}

Luria- Bertani broth (LB) used to propagate bacterial strains at $370 \mathrm{C}$ with vigorous aeration. For solidification the medium, 1.5 $\%$ of agar was added (Davis et al., 1982). LB agar plates plus $1 \%$ skim milk was used to detect the production of alkaline proteases, i.e., a clear zone, that illustrate and express the hydrolysis of skim milk, gave a marker for protease production after incubation at $370 \mathrm{C}$ for 40 hours under alkaline conditions (Adinarayana and Ellaiah, 2003). Alkaline agar medium was used to subculture bacterial strains from frozen stock cultures (Takami et al., 1989). GYP medium used as production medium of alkaline protease (Roja and Prasad, 2012). Media were sterilized by autoclaving at 1210C for 20 minutes under pressure of 15 lb/square inch.

\section{Isolation and Screening of Bacterial Isolates}

Samples of agricultural soil were collected from nine different districts distributed widely between south, center and north of Jeddah province, Saudi Arabia. We tried as much as possible to collect soil samples from diverse locations. Soil samples were collected by scraping off approximately 100 gmfrom 5-10 cm below surface layer with a sterile spatula and then stored at $40 \mathrm{C}$ until use. About $1.5 \mathrm{gm}$ from each soil sample was added to $10 \mathrm{ml}$ sterilized distilled water 
in a glass tube. The glass tube containing soil suspension was heated at $80^{\circ} \mathrm{C}$ for 15 $20 \mathrm{~min}$ in a water bath. They immediately cooled in ice-cold water.LB plus skim milk agar plate was used to detect the alkaline protease production according to Adinarayana and Ellaiah (2003).

It is worth mentioning that skim milk was added to LB agar medium after sterilized and cooling at 370C.Protease production in plates was demonstrated by the clearing of opaque milk proteins surrounding colonies that growing on the plate surface. Samples of $100 \mu \mathrm{l}$ of soil suspension were spread on LB agar plus $1 \%$ skim milk plate and then incubated at $30^{\circ} \mathrm{C}$ for $48 \mathrm{~h}$. Colonies forming diaphanous zones due to partial hydrolysis of skim milk were selected, picked and purified by streaking on skim milk agar. The purified proteolytic selected isolates were examined microscopically, maintained in LB agar slants by sub culturing at monthly intervals, and stored at $4^{\circ} \mathrm{C}$.

\section{Identification of Selected Bacterial Isolates}

Fifty-four local isolates were isolated in this study as shown in Table (1). These isolates representing different regions isolated from nine different districts distributed widely between south, center and north of Jeddah province, Saudi Arabia. We coded isolates according to the locality, i.e., places from which the soil sample originated. Selected isolates, which showed good ability to produce protease enzyme were subjected to some morphological, physiological and biochemical studies in accordance with Bergey's Manual of Systematic Bacteriology (Khan et al., 2011). Gram stain, capsule stain, motility, growth with $5 \% \mathrm{NaCl}$, glucose fermentation, utilization of citrate, catalase activity and starch hydrolysis were determined. Pure stock cultures of these selected bacterial isolates were maintained in LB broth medium with $70 \%$ glycerol and preserved at $-200 \mathrm{C}$.

\section{Alkaline Protease Production}

GYP production medium $(50 \mathrm{~m} 1$ in $250 \mathrm{~m} 1$ conical flask) was inoculated with $1 \mathrm{ml}$ of an overnight culture of tested strains and incubated at $370 \mathrm{C}$ in a rotary shaker operated at $150 \mathrm{rpm}$ for 12-hour at time intervals; the turbidity of the culture was determined by measuring the increase in optical density at $450 \mathrm{~nm}$ with a spectrophotometer. After incubation, production medium was centrifuged at 8000 rpm for $15 \mathrm{~min}$ to separate the cells. The supernatant was collected as it contained the crude enzyme and stored at 40C until further use.

\section{Alkaline Protease Assay}

One $\mathrm{ml}$ of $2 \%$ casein solution was incubated with $0.1 \mathrm{ml}$ of enzyme solution and $0.9 \mathrm{ml}$ of sodium phosphate buffer $(\mathrm{pH} 7)$ for 10 minutes at $370 \mathrm{C}$. The reaction mixture was stopped by using Trichloroacetic acid solution (10\%). After 20 minutes, the mixture was centrifuged at $8000 \mathrm{rpm} / 5 \mathrm{~min}$. Color intensity of supernatant was read at $280 \mathrm{~nm}$. The enzyme activity was calculated from standard curve of tyrosine already prepared. One unit enzyme activity was taken as the amount of enzyme producing $1 \mu \mathrm{g}$ of tyrosine under standard assay conditions and expressed as unit/ $\mathrm{ml}$ enzyme (Boominadhan et al., 2009).

\section{Strain Improvement Techniques}

\section{Microorganism and Inoculum Preparation}

The selected tested bacterial strains were subjected to mutagenesis via physical and chemical mutagens. A loopful of each stock 
tested strain culture was transferred to 100 $\mathrm{ml}$ of sterile LB broth medium then incubated overnight at $350 \mathrm{C}$ on a rotary shaker before being used to inoculation (Rajuand Divakar, 2013).

\section{Physical Mutagenesis using UV Radiation}

Best production strains were subjected to mutagenesis using UV radiation according to Justin et al., (2001) using different exposure times and different distances from irradiation source. A 24-hour old loopful culture of each strain was transferred from slant into $50 \mathrm{ml} \mathrm{LB}$ broth and incubated at $370 \mathrm{C}$ for 12-hour. After that, ten $\mathrm{ml}$ of the inoculated broth was centrifuged at 4000 rpm for $10 \mathrm{~min}$ at 40C. The supernatant was removed and the cell pellets was washed with sterile saline followed by sterile distilled water. Finally the cell mass was suspended in sterile saline and used as a source of cell suspension in irradiation experiment and later experiments. Various serial dilutions of cell suspension were prepared and the dilution of both 10-5 and $10-7 / \mathrm{ml}$ distributed into different round sterilized disposable petri dishes $(2 \mathrm{ml}$ in each petri plate) in dark. Then, they irradiated for $0,10,20$ and $40 \mathrm{~min}$ in UV chamber keeping the distance of UV source fixed at 5, 11.5 and $20 \mathrm{~cm}$. 15-W germicidal lamp (254 nm) used. To avoid any repair in DNA, which damaged because of UV light, the treated samples were transferred into sterile test tubes covered with a black paper and kept in the refrigerator overnight. Half ml of suitable dilution of each strain was spread on skim milk agar plates and incubated for 24-hour at 370C. Colonies that developed after incubation was counted and the survival percentage was calculated over the control, where a less than $10 \%$ survival rate was observed. Werandomly selected the colonies, transferred onto skim milk plates and checkedfor production of protease based on the zone formation compared to what has been obtained by parental strains. Mutants of hyperactive production that showing bigger zones were picked up. The mutants were cultured at least five times to emphasize incapability of reverse mutation.

\section{Chemical Mutagenesis using Ethidium Bromide (EtBr)}

Mutagenesis carried out according to (Fakhraddin et al., 2014). Five $\mathrm{ml}$ of the cell suspension containing $1 \times 107 / \mathrm{ml}$ of each strain was pipette aseptically into separate individual sterilized centrifuged tubes and $\mathrm{EtBr}$ was added at concentration of (75 and $150 \mathrm{mg} / \mathrm{ml}$ ) and kept them in water bath at $370 \mathrm{C}$ for different time intervals, $0,30,60$ and $120 \mathrm{~min}$. After a specific time interval, sample of one $\mathrm{ml}$ was pulled, centrifuged at $10,000 \mathrm{rpm}$ for one minute and cell pellet washed three times with normal in order to get rid of mutagen from sample. We dilute the suspension of the washed cells serially in saline, spread on LB skim milk agar plates and incubated for 48 hours at 370C. In each plate, number of colonies was counted and the survival percentage was calculated over the control. Mutants of hyperactive production of protease that showing bigger zones compared to the parental strain were picked up.

\section{Plasmid Curing}

Plasmid curing is a process of eliminating bacterial plasmids through means of methods including physical agents such as elevated temperature and chemical agents such as acridine orange that used in this study. Parental strains and their bestderivatived mutants were subjected to curing to find out the effect of these two agents on their enzyme productivity. Curing of plasmids with elevated temperature was carried out following the method of (Soliman et al., 2003). To achieve curing by heat treatment, each strain was grown in LB 
broth medium at temperature $5-7^{\circ} \mathrm{C}$ above its optimum growth temperature on a rotary shaker at $150 \mathrm{rpm} / \mathrm{min}$. When culture arrived to late log phase, it diluted to a dilution ratio of 1:20. Then we re-incubated sample culture at the same incubation degree until late log phase reached again. We prepared and plated a serial dilution to obtain single colonies. The colonies are individually tested on LB plus $1 \%$ skim milk plates for wastage of plasmids that causing any shortage in the ability of cured strains to produce protease enzyme. Curing of plasmids using acridine orange (AO) was conducted in accordance with the method of Zaman et al., (2010). To achieve curing by (AO), two different concentrations of acridine orange $(50 \mu \mathrm{g} / \mathrm{ml}$ and $75 \mu \mathrm{g} / \mathrm{ml})$ using different exposure times (30 and 60 min) were used. An overnight culture of each tested strain was diluted to 104 cells $/ \mathrm{ml}$ using freshly LB broth medium by serial dilution technique. From this diluted culture, $0.5 \mathrm{ml}$ was added with $4.5 \mathrm{ml} \mathrm{LB}$ containing (AO) separately in different concentrations. Thus, the concentration became 103 cells $/ \mathrm{ml}$. The cultures were then incubated at $370 \mathrm{C}$ in an orbital shaker at $150 \mathrm{rpm}$ for 24 hours. After incubation, the broth culture was again diluted to 103 cells $/ \mathrm{ml}$ with sterile normal saline to avoid the chemical effects. Appropriate volume was spread on LB plus $1 \%$ skim milk plates. After 24-hour incubation at $37^{\circ} \mathrm{C}$, the plates were observed for growth. Some well-isolated colonies from this plate culture were randomly selected and simultaneously patched with sterile toothpick on LB agar plus $1 \%$ skim milk. They tested for loss of its ability to produce alkaline protease enzyme.

\section{Results and Discussion}

\section{Isolation, Identification and Screening of Protease -producing Bacterial Strains}

Fifty-four bacterial isolates were isolated from soil samples collected from nine different regions and coded according to the locality, i.e., districts from which the soil sample originated as shown in (Table 1). Results shown in (Table 2) explained the enzyme activities of these isolates, which showed a broad range of productivity. Morphological, physiological and biochemical properties of the highest productive isolates were investigated in accordance with Bergey's Manual of Systematic Bacteriology (Khan et al., 2011). Gram stain, motility, starch hydrolysis, glucose fermentation, nitrate reduction, catalase activity and growth with $5 \% \mathrm{NaCl}$ were determined. Finally, they were identified as Bacillus spp. and assigned as Bacillus BS, BP, BT and BL as shown in (Table 3).

\section{Determination of Enzyme Activity of Selected Bacterial Strains}

To detect the alkaline protease production for all tested bacterial isolates, LB plus $1 \%$ skim milk plates were used following the method of Adinarayana and Ellaiah (2003). Alkaline protease production was assayed for all isolates(Boominadhan et al., 2009) and results shown in (Table 2) showed a broad range of productivity, i.e., 1.34 to 10.76 U/ml, The highest four isolates were J1, KA6, F5 and M4, i.e., 10.76, 10.50, 10.30 and $9.36 \mathrm{U} / \mathrm{ml}$, respectively.

\section{Strain Improvement and Selection of Overproducing mutants}

Both mutagen agents UV irradiation and ethidium bromide (EtBr) were employed in systematic manner to obtain mutants that yield higher protease production. The parent strains BT, BL, BS and BP were treated with UV irradiation for $0,10,20$ and $40 \mathrm{~min}$ in UV chamber keeping the distance of UV source fixed at 5, 11.5 and $20 \mathrm{~cm}$. They also subjected to $\mathrm{EtBr}$ at concentration of ( 75 and $150 \mathrm{mg} / \mathrm{ml}$ ) for different time intervals, 0 , 
30, 60 and $120 \mathrm{~min}$. For the isolation of overproducing mutants, developed colonies were picked, inoculated into LB plus $1 \%$ skim milk plates and incubated at 370C for $24 \mathrm{~h}$. Depending upon the zone of clearance, mutants with high activity compared to parental strains were selected and the enzyme activity was assayed. Results in (Table 4 and 5) revealed that after UV irradiation, the survival rate in all strains were decreased gradually whatever with the increase of exposure time, in both cell dilutions $10-5$ or $10-7$ and radiation intensities, i.e., whether distances was 5, 11.5 or $20 \mathrm{~cm}$. On the other hand, results showed that the decreasing in survival percentages was highest in a distance of 5 $\mathrm{cm}$ when compared to other distances. In addition, the decreasing was also highest at a dilution of 10-5 compared to 107.Generality, survival was sharply reduced and became $0 \%$ in most results. Similar trend of decrease in survivability with increase in exposure time has also been reported by some other studies (Soliman et al., 2005; Shikha and Darmwal, 2007; Mukhtar and Haq 2008; Javed et al., 2013). All these findings indicated that the survivability of parent strains depended on the nature of the microorganisms, treatment period and the type of mutagens (Javed et al., 2013). Regarding to EtBr treatments, results in (Table 6) revealed that the survival percentage in all strains was decreased gradually with the increase of exposure time in both concentration of $\mathrm{EtBr}$ whether in concentration of $75 \mathrm{or} 150 \mathrm{mg} / \mathrm{ml}$. Survival percentage at exposure time of $120 \mathrm{~min}$ became $0 \%$ in both concentration of $\mathrm{EtBr}$. In case of exposure time $60 \mathrm{~min}$, we found various results, which proved that the survival rate in all strains decreased gradually with $150 \mathrm{mg} / \mathrm{ml}$ concentration of EtBr compared to $75 \mathrm{mg} / \mathrm{ml}$. Results in (Table 7) for UV irradiation treatment and (Table 8) for EtBr treatment showed the values of enzyme activities for both parents and their resulting mutations. Mutant strains showed different responses to UV irradiation for alkaline protease production. Results showed a broad range of productivity and the highest four mutants were, BL4-1, RS6-1, BETL0-1 and BETP40-2, i.e., 25.98, 22.10, 19.74 and $14.92 \mathrm{U} / \mathrm{ml}$, respectively. Mutant BL4-1 that resulted from Bacillus BL where it gave productivity threefold than parental strain while RS6-1 mutant that resulted from Bacillus BS gave two fold obtained highest enzyme productivity $(25.98 \mathrm{U} / \mathrm{ml})$. Results also showed that treatments with UV irradiation were more efficient than $\mathrm{EtBr}$ to increase the productivity of protease enzyme. These results may be due to increasing in gene copy number and amplification of DNA region. The variations are more probably due to the differences in genetic background of strains. Therefore, the results that obtained revealed variation in gene expression, i.e., enzyme activity as reported by Justin et al. (2001). Variations perhaps also due to some factors, e.g., deterioration or mutation occurs in gene(s), differences in the ability to repair their DNA, damage of the repair enzymes and the repair mechanism is not universal, as a result, replication cannot occur again (Ben, 2003).Uehara et al. (1974) suggested the existence of regulator genes that responsible for protease production. In addition, mutations that led to the higher production of proteases may also encompass those genes, which could alter the productivity, instead of the structure genes themselves. Nagami and Tanaka (1986) proved that mutation of genes controlling the composition of cell membrane led to the hyperactive production of proteases. They also pointed to the effect of mutations on regulatory genes, which are associated with the structural genes. However, the application of UV irradiation, whatever the 
mutation(s) include either modifying or structural genes, led to the isolation of hyperactive producing cultures (Qadeer et al., 1980).Similar results were consistent with the results obtained in this study. Jamal et al. (2011) use UV irradiation in strain improvement. They revealed that the percentages of survival were decreased by increasing both of radiation intensities, i.e., distances and time of exposure. They obtained three mutants with high lipase production after being treated with UV, where these mutants gave production equivalent to $1.2,2.6$ and 4 folds than obtained by original strain. On another hand, Soliman et al. (2005) used Bacillus pumilus and Bacillus alvei to investigate the changes in gene expression that responsible for protease production after conducting UV irradiation. They indicated that no enzyme activity was scored with derived mutants resulting from $B$. pumilus, while the activity was pronounce, in derived mutants resulting from $B$. alvei. They obtained three mutants that yield higher production in comparison to parental strain. These activities were 2.6, 3.02 and 3.7 folds than production obtained from the original strains. In addition, Hungund and Gupta (2010)proved the efficiency of UV irradiation for strain improvement. They obtained higher cellulose production mutants resulted from Gluconacetobacter xylinus NCIM 2526 wild strain.

Table.1 Bacillus Isolates

\begin{tabular}{|c|c|c|c|c|c|}
\hline Region & Isolate No. & Code & Region & Isolate No. & Code \\
\hline \multicolumn{3}{|c|}{ SOUTH JEDDAH } & & 28 & SH5 \\
\hline \multirow{4}{*}{$\begin{array}{l}\text { MADAIN } \\
\text { AL-FAHD }\end{array}$} & 1 & M1 & & 29 & SH6 \\
\hline & 2 & M2 & & 30 & SH7 \\
\hline & 3 & M3 & \multirow[t]{6}{*}{ AL- KANDARAH } & 31 & KA1 \\
\hline & 4 & M4 & & 32 & KA2 \\
\hline \multirow[t]{6}{*}{ AL-HINDAWIYA } & 5 & $\mathrm{H} 1$ & & 33 & KA3 \\
\hline & 6 & $\mathrm{H} 2$ & & 34 & KA4 \\
\hline & 7 & $\mathrm{H} 3$ & & 35 & KA5 \\
\hline & 8 & $\mathrm{H} 4$ & & 36 & KA6 \\
\hline & 10 & H6 & \multicolumn{3}{|c|}{ NORTH JEDDAH } \\
\hline & 11 & $\mathrm{H} 7$ & \multirow[t]{5}{*}{ AL-FAISALYA } & 37 & F1 \\
\hline \multirow[t]{7}{*}{ AL-WAZIRIYAH } & 12 & W1 & & 38 & $\mathrm{~F} 2$ \\
\hline & 13 & W2 & & 39 & F3 \\
\hline & 14 & W3 & & 40 & $\mathrm{~F} 4$ \\
\hline & 15 & W4 & & 41 & F5 \\
\hline & 16 & W5 & \multirow[t]{7}{*}{ AL-SAFA } & 42 & S1 \\
\hline & 17 & W6 & & 43 & S2 \\
\hline & 18 & W7 & & 44 & S3 \\
\hline CEN & TER JEDDA & & & 45 & S4 \\
\hline \multirow[t]{5}{*}{ AL-JAMAA } & 19 & $\mathrm{~J} 1$ & & 46 & S5 \\
\hline & 20 & $\mathrm{~J} 2$ & & 47 & S6 \\
\hline & 21 & $\mathrm{~J} 3$ & & 48 & S7 \\
\hline & 22 & $\mathrm{~J} 4$ & \multirow[t]{6}{*}{ AL- KHALIDIYA } & 49 & K1 \\
\hline & 23 & J5 & & 50 & $\mathrm{~K} 2$ \\
\hline \multirow{4}{*}{ AL-SHARAFYA } & 24 & SH1 & & 51 & K3 \\
\hline & 25 & $\mathrm{SH} 2$ & & 52 & $\mathrm{~K} 4$ \\
\hline & 26 & SH3 & & 53 & K5 \\
\hline & 27 & SH4 & & 54 & K6 \\
\hline
\end{tabular}


Table.2. Alkaline Protease Activity of Bacillus isolates at pH 9.

\begin{tabular}{|l|l|l|l|l|l|}
\hline Isolates code & $\begin{array}{l}\text { Enzyme } \\
\text { activity U/ml }\end{array}$ & $\begin{array}{l}\text { Isolates } \\
\text { code }\end{array}$ & $\begin{array}{l}\text { Enzyme } \\
\text { activity U/ml }\end{array}$ & $\begin{array}{l}\text { Isolates } \\
\text { code }\end{array}$ & $\begin{array}{l}\text { Enzyme activity } \\
\text { U/ml }\end{array}$ \\
\hline M1 & -- & J1 & $\mathbf{1 0 . 7 6}$ & F1 & -- \\
\hline M2 & 2.50 & J2 & -- & F2 & -- \\
\hline M3 & 3.00 & J3 & 8.65 & F3 & 1.34 \\
\hline M4 & $\mathbf{9 . 3 6}$ & J4 & 5.87 & F4 & 5.82 \\
\hline H1 & -- & J5 & -- & F5 & $\mathbf{1 0 . 3 0}$ \\
\hline H2 & 1.75 & SH1 & -- & S1 & \\
\hline H3 & -- & SH2 & 7.00 & S2 & -- \\
\hline H4 & -- & SH3 & -- & S3 & -- \\
\hline H5 & -- & SH4 & 5.88 & S4 & 2.98 \\
\hline H6 & -- & SH5 & 3.55 & S5 & -- \\
\hline H7 & 4.00 & SH6 & -- & S6 & 5.34 \\
\hline W1 & 2.80 & SH7 & 1.34 & S7 & 3.82 \\
\hline W2 & 7.90 & KA1 & 6.82 & K1 & -- \\
\hline W3 & 5.04 & KA2 & 4.87 & K2 & -- \\
\hline W4 & -- & KA3 & 7.43 & K3 & -- \\
\hline W5 & -- & KA4 & 3.40 & K4 & 5.74 \\
\hline W6 & 1.90 & KA5 & -- & K5 & 8.82 \\
\hline W7 & 8.76 & KA6 & $\mathbf{1 0 . 5 0}$ & K6 & -- \\
\hline
\end{tabular}

(--): undetected amount of enzyme production. One enzyme unit was defined as the amount of enzyme that yields an increase of 0.1 OD at $420 \mathrm{~nm} / 30 \mathrm{~min}$ under standard reaction conditions.

Table.3 Morphological and Biological Characterization of Bacillus isolated strains

\begin{tabular}{|l|l|l|l|l|l|l|l|l|}
\hline \multirow{2}{*}{$\begin{array}{l}\text { Isolate } \\
\text { Code }\end{array}$} & $\begin{array}{l}\text { Morphological } \\
\text { characteristics }\end{array}$ & \multicolumn{5}{|c|}{ Biological characteristics } & Name \\
\cline { 2 - 9 } & $\begin{array}{l}\text { Gram } \\
\text { stain }\end{array}$ & Motility & $\begin{array}{l}\text { Starch } \\
\text { hydrolysis }\end{array}$ & $\begin{array}{l}\text { Glucose } \\
\text { fermentation }\end{array}$ & $\begin{array}{l}\text { NO3 } \\
\text { reduction }\end{array}$ & $\begin{array}{l}\text { Catalase } \\
\text { activity }\end{array}$ & $\begin{array}{l}\text { Growth } \\
\text { at 5\% } \\
\text { NaCl }\end{array}$ & \\
\hline KA6 & + & Present & + & + & - & + & - & Bacillus BP \\
\hline M4 & + & Present & + & + & + & + & + & Bacillus BL \\
\hline F5 & + & Present & + & + & + & + & + & Bacillus BT \\
\hline J1 & + & Present & + & - & + & + & - & Bacillus BS \\
\hline
\end{tabular}

*Spore shape $(\mathrm{O}=$ oval and $\mathrm{R}=$ round $),{ }^{* *}$ Spore location $(\mathrm{T}=$ Terminal, $\mathrm{C}=$ central and $\mathrm{S}=$ sub-terminal $)$

Fig.1 Zones of clearance on skim milk agar plates produced by parent strain Bacillus BL (BL0-1) and some of its various mutants after UV irradiation
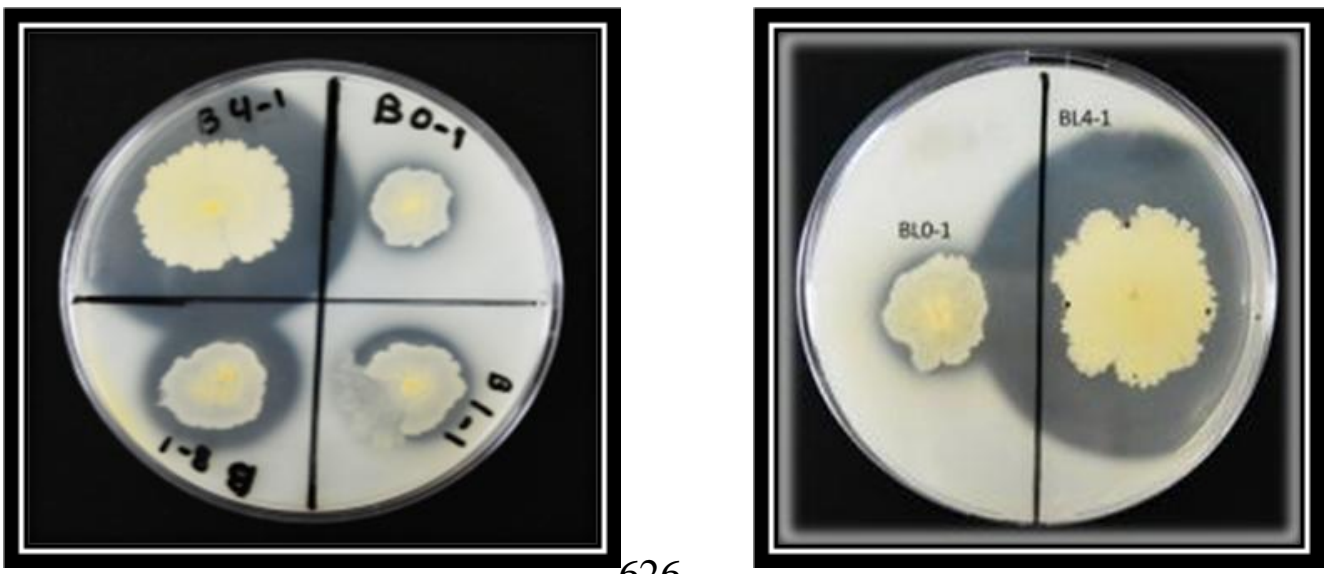
Table.4 Survival Percentage of Bacillus strains after UV Irradiation at 10-5cell dilution

\begin{tabular}{|c|c|c|c|c|c|c|c|}
\hline \multirow[t]{2}{*}{ Strains } & \multirow[t]{2}{*}{$\begin{array}{l}\text { Exposure } \\
\text { time } \\
\text { inmin. }\end{array}$} & $\begin{array}{l}\text { No. of cells } \\
\text { after } \\
\text { irradiation }\end{array}$ & $\begin{array}{l}\text { Survival } \\
(\%)\end{array}$ & $\begin{array}{l}\text { No. of cells } \\
\text { after } \\
\text { irradiation }\end{array}$ & $\begin{array}{l}\text { Survival } \\
(\%)\end{array}$ & $\begin{array}{l}\text { No. of cells } \\
\text { after } \\
\text { irradiation }\end{array}$ & $\begin{array}{l}\text { Survival } \\
(\%)\end{array}$ \\
\hline & & \multicolumn{2}{|c|}{ Distance of $5 \mathrm{~cm}$} & \multicolumn{2}{|c|}{ Distance of $11.5 \mathrm{~cm}$} & \multicolumn{2}{|c|}{ Distance of $20 \mathrm{~cm}$} \\
\hline \multirow{4}{*}{$\begin{array}{l}\text { Bacillus } \\
\text { BT }\end{array}$} & 0 & 301 & 100 & 295 & 100 & 285 & 100 \\
\hline & 10 & 68 & 22.59 & 109 & 36.94 & 169 & 59.29 \\
\hline & 20 & 7 & 2.32 & 13 & 4.40 & 23 & 8.07 \\
\hline & 40 & 0 & 0 & 0 & 0 & 3 & 1.05 \\
\hline \multirow{4}{*}{$\begin{array}{l}\text { Bacillus } \\
\text { BL }\end{array}$} & 0 & 244 & 100 & 234 & 100 & 223 & 100 \\
\hline & 10 & 45 & 18.44 & 65 & 27.77 & 84 & 37.66 \\
\hline & 20 & 4 & 1.63 & 10 & 4.27 & 17 & 7.62 \\
\hline & 40 & 1 & 0.40 & 1 & 0.42 & 5 & 2.24 \\
\hline \multirow{4}{*}{$\begin{array}{l}\text { Bacillus } \\
\text { BS }\end{array}$} & 0 & 304 & 100 & 322 & 100 & 340 & 100 \\
\hline & 10 & 48 & 15.78 & 70 & 21.73 & 98 & 28.82 \\
\hline & 20 & 5 & 1.64 & 7 & 2.17 & 19 & 5.58 \\
\hline & 40 & 0 & 0 & 0 & 0 & 4 & 1.17 \\
\hline \multirow{4}{*}{$\begin{array}{l}\text { Bacillus } \\
\text { BP }\end{array}$} & 0 & 205 & 100 & 180 & 100 & 190 & 100 \\
\hline & 10 & 30 & 14.63 & 54 & 30 & 70 & 36.84 \\
\hline & 20 & 4 & 1.95 & 19 & 10.55 & 13 & 6.84 \\
\hline & 40 & 0 & 0 & 2 & 1.11 & 3 & 1.57 \\
\hline
\end{tabular}

Table.5 Survival percentage of Bacillus strains after UV irradiation at 10-7 cell dilution

\begin{tabular}{|c|c|c|c|c|c|c|c|}
\hline \multirow[t]{2}{*}{ Strains } & \multirow{2}{*}{$\begin{array}{l}\text { Exposure } \\
\text { time } \\
\text { inmin. }\end{array}$} & $\begin{array}{l}\text { No. of cells } \\
\text { after } \\
\text { irradiation }\end{array}$ & $\begin{array}{l}\text { Survival } \\
(\%)\end{array}$ & $\begin{array}{l}\text { No. of cells } \\
\text { after } \\
\text { irradiation }\end{array}$ & $\begin{array}{l}\text { Survival } \\
(\%)\end{array}$ & $\begin{array}{l}\text { No. of cells } \\
\text { after } \\
\text { irradiation }\end{array}$ & $\begin{array}{l}\text { Survival } \\
(\%)\end{array}$ \\
\hline & & \multicolumn{2}{|c|}{ Distance of $5 \mathrm{~cm}$} & \multicolumn{2}{|c|}{ Distance of $11.5 \mathrm{~cm}$} & \multicolumn{2}{|c|}{ Distance of $20 \mathrm{~cm}$} \\
\hline \multirow{4}{*}{$\begin{array}{l}\text { Bacillus } \\
\text { BT }\end{array}$} & 0 & 120 & 100 & 109 & 100 & 118 & 100 \\
\hline & 10 & 25 & 20.83 & 33 & 30.27 & 45 & 38.13 \\
\hline & 20 & 1 & 0.83 & 4 & 3.66 & 9 & 7.62 \\
\hline & 40 & 0 & 0 & 0 & 0 & 0 & 0 \\
\hline \multirow{4}{*}{$\begin{array}{l}\text { Bacillus } \\
\text { BL }\end{array}$} & 0 & 88 & 100 & 90 & 100 & 98 & 100 \\
\hline & 10 & 16 & 18.18 & 24 & 26.66 & 32 & 32.65 \\
\hline & 20 & 0 & 0 & 3 & 3.33 & 5 & 5.10 \\
\hline & 40 & 0 & 0 & 0 & 0 & 0 & 0 \\
\hline \multirow{4}{*}{$\begin{array}{l}\text { Bacillus } \\
\text { BS }\end{array}$} & 0 & 95 & 100 & 105 & 100 & 100 & 100 \\
\hline & 10 & 20 & 21.05 & 25 & 23.80 & 36 & 36 \\
\hline & 20 & 0 & 0 & 2 & 1.90 & 3 & 3 \\
\hline & 40 & 0 & 0 & 0 & 0 & 0 & 0 \\
\hline \multirow{4}{*}{$\begin{array}{l}\text { Bacillus } \\
\text { BP }\end{array}$} & 0 & 75 & 100 & 83 & 100 & 85 & 100 \\
\hline & 10 & 12 & 16 & 15 & 18.07 & 21 & 24.70 \\
\hline & 20 & 0 & 0 & 0 & 0 & 1 & 1.17 \\
\hline & 40 & 0 & 0 & 0 & 0 & 0 & 0 \\
\hline
\end{tabular}


Table.6 Survival Percentage of Bacillus strains after EtBr treatment

\begin{tabular}{|c|c|c|c|c|c|}
\hline \multirow[t]{2}{*}{ Strains } & \multirow[t]{2}{*}{$\begin{array}{l}\text { Exposure } \\
\text { time inmin. }\end{array}$} & $\begin{array}{l}\text { No. of cells } \\
\text { after EtBr } \\
\text { treatment }\end{array}$ & Survival (\%) & $\begin{array}{l}\text { No. of cells } \\
\text { after EtBr } \\
\text { treatment }\end{array}$ & Survival (\%) \\
\hline & & \multicolumn{2}{|c|}{ Concentration of $75 \mu \mathrm{g} / \mathrm{ml}$} & \multicolumn{2}{|c|}{ Concentration of $150 \mu \mathrm{g} / \mathrm{ml}$} \\
\hline \multirow[t]{4}{*}{ Bacillus BT } & 0 & 533 & 100 & 550 & 100 \\
\hline & 30 & 87 & 16.32 & 18 & 3.27 \\
\hline & 60 & 20 & 3.75 & 1 & 0.18 \\
\hline & 120 & 0 & 0 & 0 & 0 \\
\hline \multirow[t]{4}{*}{ Bacillus BL } & 0 & 480 & 100 & 453 & 100 \\
\hline & 30 & 61 & 12.70 & 22 & 4.85 \\
\hline & 60 & 12 & 2.5 & 0 & 0 \\
\hline & 120 & 0 & 0 & 0 & 0 \\
\hline \multirow[t]{4}{*}{ Bacillus BS } & 0 & 560 & 100 & 577 & 100 \\
\hline & 30 & 70 & 12.5 & 31 & 5.37 \\
\hline & 60 & 19 & 3.39 & 4 & 0 \\
\hline & 120 & 0 & 0 & 0 & 0 \\
\hline \multirow[t]{4}{*}{ Bacillus BP } & 0 & 404 & 100 & 420 & 100 \\
\hline & 30 & 91 & 22.52 & 27 & 6.42 \\
\hline & 60 & 32 & 7.92 & 2 & 0.47 \\
\hline & 120 & 0 & 0 & 0 & 0 \\
\hline
\end{tabular}

Table.7 Enzyme Activities of Parental Strains and their best Mutants arising after UV Treatment

\begin{tabular}{|c|c|c|c|}
\hline Strains & Enzyme activity U/ml & Strains & Enzyme activity U/ml \\
\hline \multicolumn{2}{|c|}{$\begin{array}{l}\text { Bacillus BL parental strain and their best } \\
\text { derived mutants }\end{array}$} & \multicolumn{2}{|c|}{$\begin{array}{c}\text { Bacillus BS parental strain and their best } \\
\text { derived mutants }\end{array}$} \\
\hline BL (B0-1) & 9.36 & Bacillus BS & 10.76 \\
\hline BL1-1 & 9.88 & RS6-1 & 12.28 \\
\hline BL4-1 & 25.98 & RST5 & 22.10 \\
\hline BL8-1 & 12.02 & RS18-1 & 12.66 \\
\hline BL33-1 & 13.50 & RS24-1 & 15.62 \\
\hline BL42-1 & 12.34 & RS47-1 & 13.60 \\
\hline \multicolumn{2}{|c|}{$\begin{array}{c}\text { Bacillus BP parental strain and their best } \\
\text { derived mutants }\end{array}$} & \multicolumn{2}{|c|}{$\begin{array}{c}\text { Bacillus BT parental strain and their best } \\
\text { derived mutants }\end{array}$} \\
\hline Bacillus BP & 10.50 & Bacillus BT & 10.30 \\
\hline BP5-1 & 12.02 & BT5-1 & 12.26 \\
\hline BP20-1 & 14.04 & BT13-1 & 12.18 \\
\hline BP22-1 & 13.12 & BT42-1 & 10.14 \\
\hline BP32-1 & 10.90 & BT48-1 & 11.10 \\
\hline BP55-1 & 12.00 & BT58-1 & 11.28 \\
\hline
\end{tabular}


Table.8 Enzyme Activities of Parental Strains and their best mutants arising after EtBr treatment

\begin{tabular}{|c|c|c|c|}
\hline Strains & Enzyme activity U/ml & Strains & Enzyme activity U/ml \\
\hline \multicolumn{2}{|c|}{$\begin{array}{l}\text { Bacillus BL parental strain and their best } \\
\text { derived mutants }\end{array}$} & \multicolumn{2}{|c|}{$\begin{array}{c}\text { Bacillus BS parental strain and their best } \\
\text { derived mutants }\end{array}$} \\
\hline Bacillus BL & 9.36 & Bacillus BS & 10.76 \\
\hline BETL1-2 & 9.80 & BETS12-2 & 12.32 \\
\hline BETL8-2 & 10.38 & BETS 23-2 & 11.98 \\
\hline BETL0-1 & 19.74 & BETS33-2 & 13.48 \\
\hline BETL28-2 & 12.32 & BETS37-2 & 13.42 \\
\hline BETL36-2 & 11.30 & BETS45-2 & 12.10 \\
\hline \multicolumn{2}{|c|}{$\begin{array}{c}\text { Bacillus BP parental strain and their best } \\
\text { derived mutants }\end{array}$} & \multicolumn{2}{|c|}{$\begin{array}{c}\text { Bacillus BT parental strain and their best } \\
\text { derived mutants }\end{array}$} \\
\hline Bacillus BP & 10.50 & Bacillus BT & 10.3 \\
\hline BETP13-2 & 13.74 & BETT9-2 & 11.2 \\
\hline BETP15-2 & 13.42 & BETT14-2 & 12.34 \\
\hline BETP35-2 & 14.08 & BETT28-2 & 12.56 \\
\hline BETP40-2 & 14.92 & BETT36-2 & 11.4 \\
\hline BETP45-2 & 13.30 & BETT41-2 & 11.54 \\
\hline
\end{tabular}

Table.9 Enzyme activity (EA) of parental strains (Bacillus BL and Bacillus BS) and some of best resulting mutants after plasmid curing by elevated temperature (ET) and acridine orange (AO) at concentration of $75 \mu \mathrm{g} / \mathrm{ml}$.

\begin{tabular}{|l|l|l|l|}
\hline Strains & EA U/ml & EA after ET treatment & EA after AO treatment \\
\hline Bacillus BL & 9.36 & 9.48 & 20.06 \\
\hline Mutant BL4-1 & 25.98 & 23 & 19.69 \\
\hline Bacillus BS & 10.76 & 19.86 & 21.86 \\
\hline Mutant RST5 & 22.10 & 9.66 & 23.12 \\
\hline
\end{tabular}

Fig.2 Zones of clearance on skim milk agar plates produced by parent strain Bacillus BS (RS0-1) and some of its various mutants after UV radiation
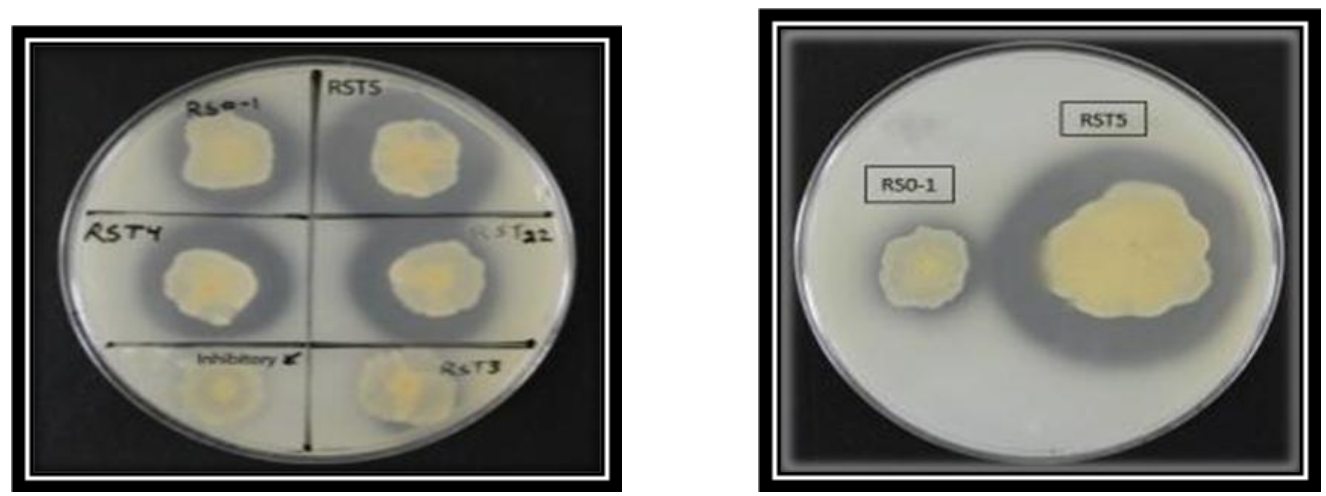
Fig.3 Zone of clearance of (A): Bacillus BL (B4-1) mutant, (B): Mutant after treatment with $(\mathrm{AO})$ and $(\mathrm{C})$ : Mutant after treatment with (ET)

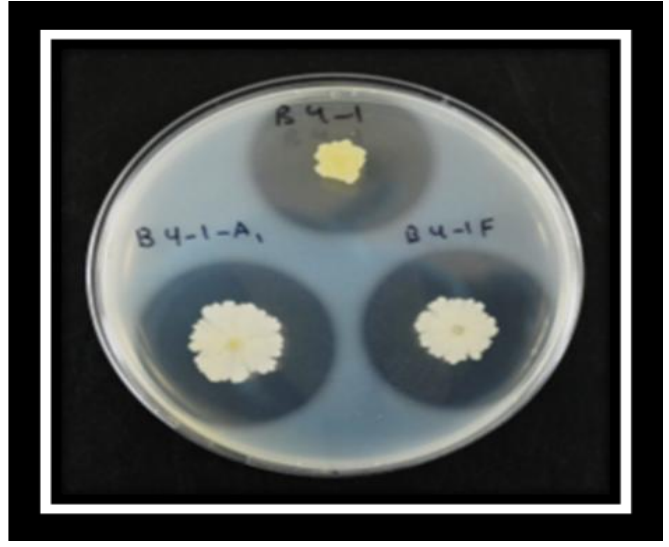

Fig.4 Zone of clearance of (A): Parental Bacillus BL (B0-1) strain, (B): Parental strain after treatment with $(\mathrm{AO})$ and $(\mathrm{C})$ : Parental strain after treatment with (ET)

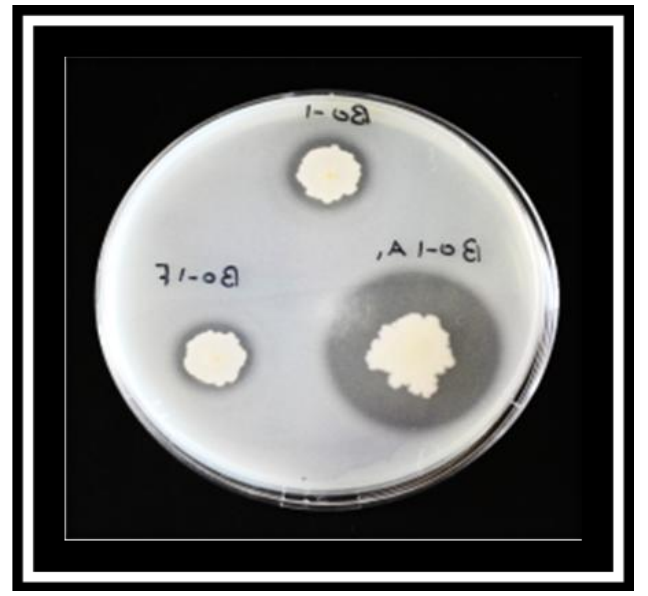

Fig.5 Zone of clearance of: (A) Mutant resulted from parental Bacillus BL strain after treated with EtBr ,(B) Mutant after curing by (ET), (C) Mutant resulted from parental Bacillus BL after treated with UV and (D) Mutant after curing by (ET).

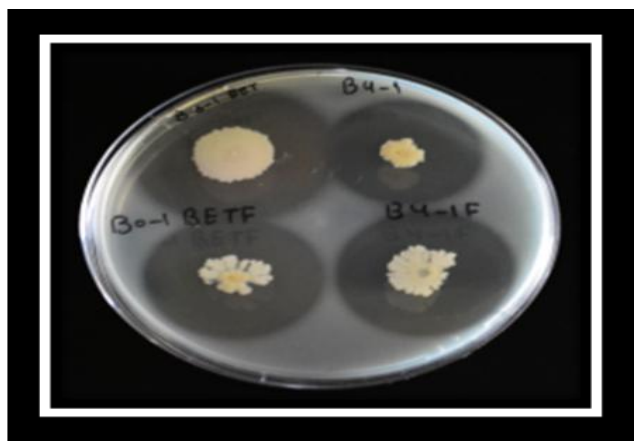


Fig.6 Zone of clearance of: (A) Parental Bacillus BS strain (RS0-1), (B) Parental strain after treated with (AO), (C) RST5 mutant resulted from parental after treated with UV and (D) after curing by

(ET).

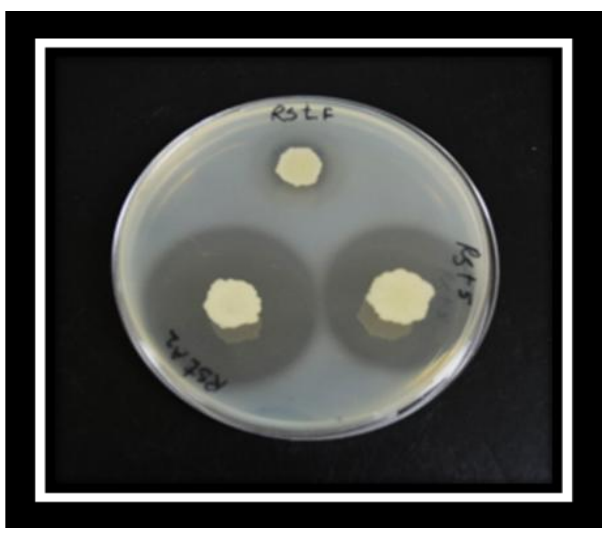

Fig.7 Zone of clearance of: (A) RST5 mutant resulted from parent Bacillus BS strain after treated with UV, (B) Mutant after curing by ET and (C) Mutant after curing by AO

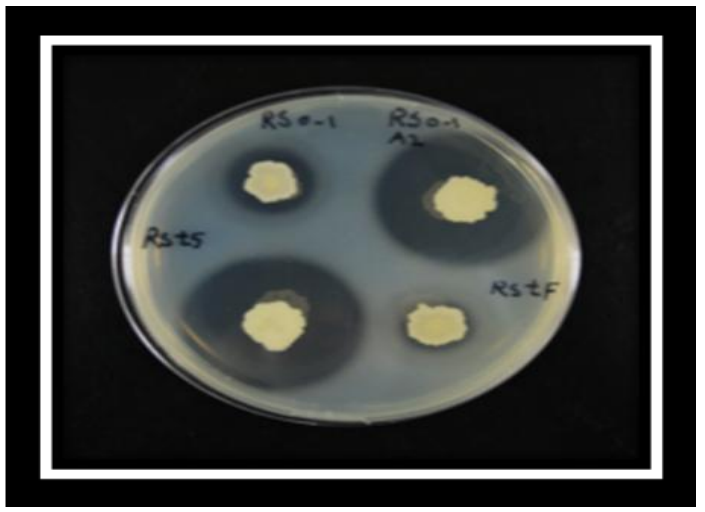

Beatriz et al. (2010) also obtained mutant from Aspergillus oryzae IPT-301 with highest value of total fructosyl transferase activity after treating with UV irradiation. Javed et al., (2013) improved the productivity of protease enzyme by subjecting Bacillus subtilis M-9 parental strain to UV-irradiations. They obtained BSU-5 mutant strain that showed the hyperactive proteolytic activity of alkaline protease over parent strain and other mutants. In contrast, Raju and Divakar (2013) enhanced the production fibrinolytic protease by subjecting Bacillus cereus to strain improvement by random mutagenesis using UV irradiation and ethidium bromide treatment. They proved that ethidium bromide was the best and most efficient for obtained optimum production of fibrinolytic protease and this was not compatible with our finding.EB-15 mutant strain was found to produce 2-4 fold more enzyme. Kumar et al., (2009) revealed that the best mutant, Bacillus sp. FME 2, selected from UV irradiation and EtBr, was shown to be the most promising and the yield of 
glucoamylase generated by the mutant strain was approximately 3.0 fold which was larger than the yield generated by the wildtype strain. Basavaraju et al., (2014) were subjected the wild strain Bacillus isolate 7 to strain improvement through UV irradiation which gave protease productivity less than mutant Bacillus isolate 7. In addition to the above listed, the same results obtained in this study were consent with other results reported by (Khodayari et al., 2014; Ghazi et al., 2014; Arotupin et al., 2014).

\section{Plasmid Curing Response}

Results in (Table 9) showed the effect of the removal of plasmids by elevated temperature (ET) and acridine orange (AO) on the enzyme activity (EA) in the two highest mutants, BL4-1 and RS6-1, compared to their parental strains. In the case of Bacillus BL parental strain, plasmid curing by elevated temperature has not any impact on production while production increased after treatment with acridine orange, reaching twice-parental production. Production in the case of BL4-1 mutant showed greater decrease by acridine orange compared by elevated temperature. Moreover, in parental strain Bacillus BS, productivity was increased two fold after curing with acridine orange while with elevated temperature the increase was medium. On the other hand production was not significantly affected after curing with acridine orange in the case of mutant RS6-1 while decrease sharply in case of elevated temperature from 22.10 to $9.66 \mathrm{U} / \mathrm{ml}$. The variations in response for curing in Bacillus strains may be due to the difference in their genome genes. Therefore, results obtained revealed variation in gene expression, i.e., enzyme activity. Jaiswal and Singh (1990) proved that the virulence of Clostridium perfringens type $\mathrm{B}$ was affected by curing due to the shortage, which occurred in toxin production while Beg and Ahmad (2000) proved that the curing of plasmid from E. coli $\mathrm{x}+$ was confirmed by defining the loss of resistance markers in the cured culture obtained after removal of this plasmid. It may be suggested that the increasing which detected in enzyme productivity can be resulted from elimination of genes existed on plasmids which have a negative impact on chromosomal genes that responsible for productivity, i.e., repression. The noticed decrease in protease productivity may be due to natural regulatory relations between indigenous existence plasmids and chromosomal gene. These strains might become a novel and interesting source of proteases enzymes with important economic features, therefore might be of potential applications in many important industries.

\section{References}

Adinarayana, K., Ellaiah, P., Prasad, D.S. 2003. Purification and Partial Characterization of Thermostable Serine Alkaline Protease from a Newly Isolated Bacillus subtilis PE11. AAPS Pharm. Sci. Tech., 4 (4):440-480.

Arotupin, D.J., Akinyele, B. J., Olaniyi, O. O. 2015. Influence of UV mutagenesis on $\beta$-mannanase production potential of Aspergillus glaucaus and Rhizopus japonicas. BMRJ, 5(6): 466-473.

Basavaraju, S., Kathera, C., Jasti, P.K. 2014. Induction of alkaline protease production by Bacillus mutants through UV irradiation. Int. J. Pharm. Sci. Rev. Res., 26(1): 78-83.

Beatriz, G.M., Castillo, B.G., Fernández, R.C., da Silva, E.S., Maiorano, A.E., Rodrigues, M.F. de Andrade. 2010. Mutagenesis of Aspergillus oryzae ipt-301 to improve the production of 
$\beta$ - fructofuranosidase. Braz. $J$. Microbiol., 41: 186-195.

Beg, A.Z., Ahmad, I. 2000. Effect of Plumbago zeylanica extract and certain curing agents on multidrug resistant bacteria of clinical origin. World J. Microbiol. Biotechnol., 16: 841-844.

Ben, F.K. 2003. Microbial repair mechanisms after UV treatment, Technical Background. Article Berson UV Techniek, 1:1-4.

Besoain, X.A., Pérez, L.M., Araya, A., Lefever, L., Sanguinetti, M., Montealegre, J.R. 2007. New strains obtained after UV treatment and protoplast fusion of native Trichoderma harzianum: their biocontrol effect on Pyrenochaeta lycopersici. Elec. J. Biotechnol., 10(4): 604-617.

Boominadhan, U., Rajakumar, R., Sivakumaar, P.K.V., Joe, M.M. 2009. Optimization of protease enzyme production using Bacillus sp. isolated from different wastes. Bot. Res. Int., 2(2): 83-87.

Chellappan, S., Jasmin, C., Basheer, S.M., Elyas, K.K., Bhat, S.G. 2006. Production, purification and partial characterization of a novel protease from marine Engyodontium album BTMFS10 under solid-state fermentation. Process Biochem., 41: 956-961.

Davis, R.W., Botstein, D., Roth, J.R. 1980. A Manual for Genetic Engineering: Advanced Bacterial Genetics. Cold Spring Harber Lab., Cold Spring Harber, New York.

Fakhraddin, K., Cebeci, Z., Ozcan, B.D. 2014. Improvement of enzyme activity of a novel native alkaline and thermophile Bacillus sp. CU-48, Producing $\alpha$-amylase and CMCase by mutagenesis. Int. J. Chem. Natur. Sci., 2(2): 97-103.

Ghazi, S., Sepahy, A.A., Azin, M., Khaje, K., Khavarinejad, R. 2014. UV mutagenesis for the overproduction of xylanase from Bacillus mojavensis PTCC 1723 and optimization of the production condition. Iran. J. Basic Med. Sci., 17(11): 844-853.

Haq, I., Ashraf, H., Rani, S., Qadeer, M.A. 2002. Biosynthesis of alpha amylase by chemically treated mutant of Bacillus subtilis GCBU-20. Pak. J. Biological Sci., 2(2): 73-75.

Hungund, B.S., Gupta, S.G. 2010. Improved production of bacterial cellulose from Gluconacetobacter Persimmonis $\mathrm{GH}-$ 2. J. Microbial Biochem. Technol., 2:127-133.

Jaiswal, N., Singh, V.P. 1990. Effect on virulence in Clostridium perfringens type B following exposure of the cells to elevated temperature or ethidium bromide. Indian J. Comp. Microbiol. Immunol. Infect. Dis., 11(3 \& 4): 125129.

Jamal, S.M.S., Effat, A.M. Soliman, Mutawakil, M.H.Z. 2011. Genetic improvement of Bacillus licheniformis for lipase production through UV irradiation. J. Biotech. Res., 11:75-81.

Jasvir, S., Vohra, R.M., Sahoo, D.K. 2004. Enhanced production of alkaline proteases by Bacillus sphaericus using fed-batch culture. Process Biochem., 39(9): 1093-1101.

Javed, S., Meraj, M., Bukhari, S.A., Irfan, R., Mahmood, S. 2013. Hyperproduction of alkaline protease by mutagenic treatment of Bacillus subtilis M-9 using agro industrial wastes in submerged fermentation. $J$. Microb. Biochem. Technol., 5(3): 074-080. 
Justin, C., Khodursky, A., Peter, B., Brown, P.O, Hanawalt, P.C. 2001. Comparative gene expression profiles following U.V exposure in wild type and SOS-deficient Escherichia coli. Genetics, 158:41-64.

Khan, F., Rizvi, M., Shukla, I., Malik, A. 2011. A novel approach for the identification of members of Enterobacteriaceae isolated from clinical samples. Biol. Med., 3: 313319.

Khodayari, F., Cebeci, Z., Ozcan, B.D. 2014. Improvement of enzyme activity of a novel native alkaline and thermophile Bacillus sp. CU-48, producing $\alpha$-amylase and CMCase by mutagenesis. Int. J. Chem. Natur. Sci., 2(2): 97-103.

Koncerova, H., Vachova, L., Chaloupka, J. 1984. Mutants of Bacillus megatereum with altered synthesis of an exocellular neutral proteinase. Folia Microbiol., 29(2): 99-103.

Kumar, G.S., Chandra, M.R.G.S., Sujana, Y.N., Reddy, B.R., Choi, Y.L. 2009. Enhanced production and partial purification of glucoamylase from mutated Bacillus sp. FME. J. Korean Soc. Appl. Biol. Chem., 52(5): 412418.

Mukhtar, H., Haq, I. 2008. Production of alkaline protease by Bacillus subtilis and its applications as deplating agents in leather processing. Pak. J. Bot., 40 (4):1673-1679.

Nadeem, M., Baig, S., Syed, Q.A., Qazi, J.I. 2006. Microbial production of alkaline proteases by locally isolated Bacillus subtilis PCSIR-5. Pak. J. Zool., 38(1): 109-114.

Nagami, Y., Tanaka, T. 1986. Molecular cloning and nucleotide sequence of a DNA fragment from Bacillus natto that enhances production of Extracellular proteases and levansucrase in Bacillus subtilis. $J$. Bacteriol., 166(1): 20 - 28.

Prakasham, R.S., Rao, C.S., Sarma, P.N. 2006. Green gram husk-an inexpensive substrate for alkaline protease production by Bacillus sp. in solid-state fermentation. Bioresou. Technol., 97(13):1449-1454.

Qadeer, M.A., Anjum, J.I., Akhtar, R. 1980. Biosynthesis of enzymes by solid substrate fermentation. Part II. Production of $\alpha$-amylase by Bacillus subtilis. Pak. J. Sci. Ind. Res., 23 (1):25-29.

Raju, E.V.N., Divakar, G. 2013. Bacillus Cereus GD 55 Strain Improvement by Physical and Chemical Mutagenesis for Enhanced Production of Fibrinolytic Protease. IJPSR, 4(5):8193.

Rani, M.R., Prasad, N.N., Sambasivarao, K.R.S. 2012. Optimization of cultural conditions for the production of alkaline protease from a mutant Aspergillus Flavus AS2. Asian J. Exp. Biol. Sci., 3: 565-576.

Roja, R.M., Prasad, N.N. 2012. Strain improvement of Aspergillus flavus for enhanced production of alkaline protease enzyme. IJSID, 2(1): 113120.

Sidney, P.C, Nathan, O.K. 1975. Compositions and uses for an alphaamylase polypeptide of Bacillus Spp. Meth. In Enz., 3: 26.

Soliman, E.A.M., Abo-Aba, S.E.M., Maysa, E. M., Gomaa, A.M. 2003. The role of plasmids on Bacillus alkaline proteases production in local isolated stains. Annals Agric.Sic., 48(2): 573584.

Soliman, E.A.M., Hegazy, W. K., Maysa, E. M. 2004. Induction of overproducing alkaline protease Bacillus mutants through UV irradiation. Arab $J$. Biotech., 8(1): 49-60. 
Stanbury, P.F., Whitaker, A., Hall, S.J. 1995. Principles of fermentation technology. Second edition, Pergamon Press, Oxford, 1-24.

Suribabu, K., Lalitha, G.T., Hemalatha, K.P.J. 2014. Strain improvement of Brevi Bacillus borostelensis R1 for optimization of $\alpha$-amylase production by mutagens. J. Microb. Biochem. Technol., 6(3): 123-127.

Takagi, M., Takada, H., Imanaka, T. 1990. Nucleotide sequence and cloning in Bacillus subtilis of the Bacillus stearothermophilus pleiotropic regulatory gene deg. T. J. Bacteriol., 172: 411-418.

Takami, H., Akiba, T., Horikaoshi, K. 1989. Production of extremely thermostable alkaline protease from Bacillus sp. No. AH-101. Appl. Microbiol. Biotechnol., 30: 120-124.
Uehara, H., Yonder, Y., Yamane, K., Maruo, B. 1974. Regulation of neutral protease productivity in Bacillus subtilis: Transformation of high protease productivity. J. Bacteriol., 119(1):82 - 92 .

Waring, M.J. 1965. Complex formation between ethidium bromide and nucleic acids. J. Mol. Biol., 13:269282.

Yang, M.Y., Ferrari, E., Henner, D.J. 1984. Cloning of the neutral protease gene of Bacillus subtilis and the use of the cloned gene to create an in vitro derived deletion mutation. $J$. Bacteriol., 161(1): 15-21.

Zaman, M.A., Pasha, M.H., Akhter, M.Z. 2010. Plasmid curing of Escherichia coli cells with ethidium bromide, Sodium Dodecyl Sulfate and acridine orange. Bangladesh J. Microbiol., 27(1): 28-31.

\section{How to cite this article:}

Effat A.M. Soliman, O.I.M. El-Hamshary and Reem S.M. Batayyib. 2016. Enhancement of Protease Production of Some Bacillus spp. Isolated from Various Regions in Jeddah City. Int.J.Curr.Microbiol.App.Sci. 5(5): 619-635. doi: http://dx.doi.org/10.20546/ijcmas.2016.505.063 